\title{
Regional socio-economic aspects in the field of coal mining
}

\author{
Sabina Irimie $^{1^{*}}$, and Gloria Popescu ${ }^{2}$ \\ ${ }^{1}$ University of Petroșani, Department of Management and Industrial Engineering, 20 Universitătiii, \\ Petroșani, Romania \\ ${ }^{2}$ Institute for Studies and Power Engineering, 1-3 Lacul Tei Boulevard, Bucharest, Romania
}

\begin{abstract}
Over time, the discovery of the deposit, the exploitation and processing of coal has led to the development and prosperity of many areas called "coal regions". In the last decades we have witnessed the closing process of many exploitation capacities (underground mines or open pit quarries) with complex socio-economic and even cultural impact in the coal region and on the continent. Debates for or against "coal" with related arguments, policies, strategies and measures at global, regional, national and local level integrate holistically from the "resource" issue to large dynamic systems (energy, climate, urbanism). The relationship between the coal industry and the socio-economic aspects is multifaceted and not yet fully explored. Our paper proposes a statistically documented research on regional development using representative socio-economic indicators. The paper is aiming to present the current socio-economic state in Jiu Valley micro-region, as a result of the structural transformations / changes in the coal industry of Romania's largest hard coal-fired coal basin.
\end{abstract}

\section{Introduction}

Romania public policies in the field of energy and climate change, with emphasis on coal industry, have as reference 5 fundamental strategic documents which set priorities at national level and propose measures to achieve the targets:

- Romania Mining Strategy 2017-2035 (2017)

- Romania National Strategy on Climate Change 2013-2020 (2013)

- Romania National Strategy for Sustainable Development 2030 (2018)

- Integrated National Plan for Energy and Climate Change 2021-2030 (Draft version 2018)

- Romania Energy Strategy 2019-2030, with 2050 forecast (2018).

The Energy Strategy 2019-2030, with 2050 forecast [1] underlines that on extreme weather conditions, coal is the basis for power supply resilience and proper functioning of the Romanian National Energy System (SEN), covering one third of the electricity demand. In 2030, the energy produced from coal is estimated at $15.8 \mathrm{TWh}$ representing a share of $20.5 \%$.

\footnotetext{
* Corresponding author: sabina.irimie@gmail.com
} 
If we look at the energy mix as a whole (Fig.1), the structure of primary energy production is diversified and balanced, making Romania, according to the Romanian Development Strategy for the next 20 years [2], a regional exception, on European level being third after Estonia and Denmark related to total energy import dependency. Coal, mainly lignite and hard coal to a much smaller extent, will still play until 2050 an important role in Romania (17.3\% contribution in the total primary energy production), for ensuring this energy independence and security of electricity supply. Using inland coal, as a strategic primary energy resource, in a cost-effective way in compliance with European environmental requirements, together with a rising renewable energy resources (RES) and nuclear use shares, represents a challenging goal for Romania but not impossible.

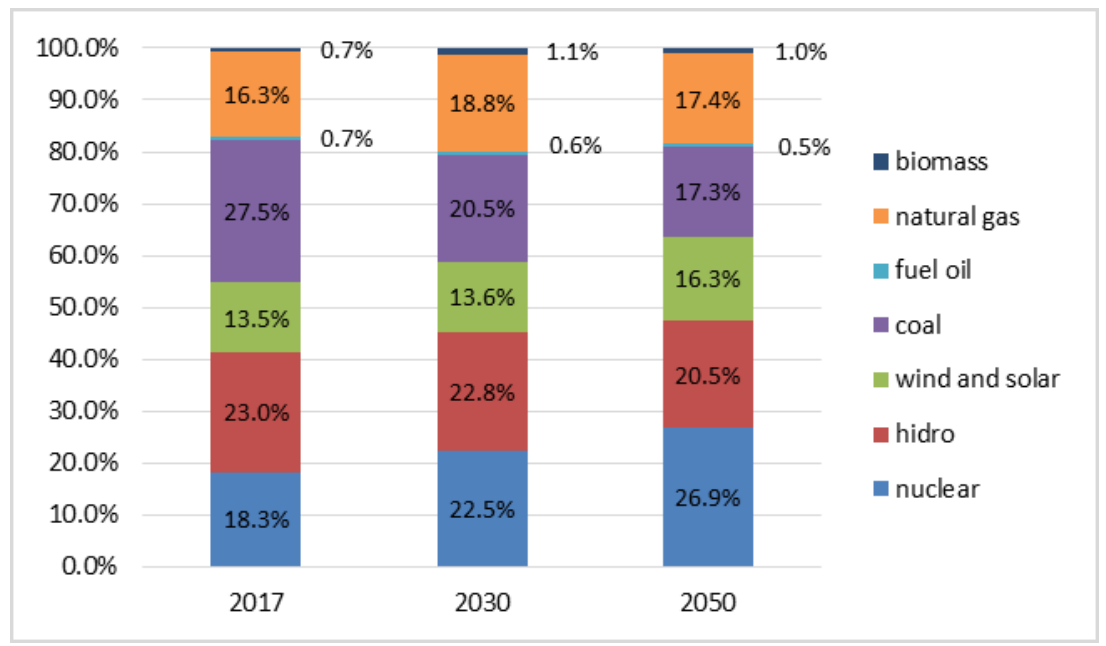

Fig. 1. Romania - Structure of the primary energy production by resources [1]

\section{Economic development}

The economic dynamics at national, regional and local level is presented in Table 1. by the following indicators: GDP per capita and contribution of economic activities to GDP. The Western Region is the second representative region of Romania, with a GDP per capita 4$6 \%$ higher than the national average in the years 2016-2017, but with discrepancies between the four component counties (ADR Vest, 2014), Timis County being the leader of the region and Hunedoara on 3rd place out of 4 component counties. West Region has seen wage growth faster than the other regions, but the existing spatial inequalities in the region have increased considerably. The current economic engines of West Region are activities in the small and medium technologic industry. Against 20 or even 10 years ago, the great transformation and challenge in this region is the transition from mining and heavy metals to light industry. Textiles, agro-food industry, ICT (including hardware, software and services) and the furniture industry, as well as car manufacturing industry (spare parts) have seen a marked upward trend, coal exploitation and use still being an important economic sector in the region, both in terms of electricity supply safety and workforce employer. Agriculture has also seen an increase due to the Banat plain's potential. Instead, the services sector recorded small increases in RDI and management consulting. It is worth mentioning the important role of strong clusters established in the last decade in the West region (e.g. ROSENC - Alternative Sustainable Energy, Automotivest Association - 
Automotive Industry, ICT, Tehimpuls Association - Innovation and Technology Transfer etc.), which contributed to the emergence and development of inter-sectoral links.

Table 1. Romania / West Region (RO42) / Jiu Valley micro-region - GDP per capita and share of main economic activities in GDP; Gross added value in the country economy. [3]

\begin{tabular}{|c|c|c|c|c|c|c|c|c|}
\hline \multirow{2}{*}{\multicolumn{2}{|c|}{ Category }} & \multirow{2}{*}{\multicolumn{3}{|c|}{ Romania }} & \multirow{2}{*}{\multicolumn{4}{|c|}{$\begin{array}{l}\text { West Region (RO42) } \\
\text { (Hunedoara County) }\end{array}$}} \\
\hline & & & & & & & & \\
\hline & years & 2015 & 2016 & 2017 & 2015 & 2016 & 2017 & 2018 \\
\hline \multirow{2}{*}{\multicolumn{2}{|c|}{ GDP per capita (euro) }} & \multirow{2}{*}{8,087} & \multirow{2}{*}{8,646} & \multirow{2}{*}{9,574} & 8,392 & 9,194 & 10,016 & 10,732 \\
\hline & & & & & 6,496 & 6,591 & 7,282 & 7,905 \\
\hline \multirow{5}{*}{$\begin{array}{c}\text { Share in } \\
\text { GDP } \\
(\%)\end{array}$} & Agriculture & 4 & 4 & 4 & 4 & 5 & N/A & N/A \\
\hline & Industry & 24 & 24 & 24 & 29 & 30 & $\mathrm{~N} / \mathrm{A}$ & $\mathrm{N} / \mathrm{A}$ \\
\hline & Construction & 6 & 6 & 6 & 4 & 4 & $\mathrm{~N} / \mathrm{A}$ & $\mathrm{N} / \mathrm{A}$ \\
\hline & ICT & 5 & 5 & 5 & 4 & 4 & $\mathrm{~N} / \mathrm{A}$ & $\mathrm{N} / \mathrm{A}$ \\
\hline & $\begin{array}{l}\text { Professional, Scientific and } \\
\text { Technical activities; activities } \\
\text { of administrative services and } \\
\text { of support services }\end{array}$ & 7 & 7 & 7 & 4 & 4 & N/A & $\mathrm{N} / \mathrm{A}$ \\
\hline \multirow{8}{*}{$\begin{array}{c}\text { Gross } \\
\text { added } \\
\text { value } \\
\text { (mil. } \\
\text { euro) } \\
\text { current } \\
\text { prices, in } \\
\text { the } \\
\text { country } \\
\text { economy }\end{array}$} & Total economy & 140,941 & 152,840 & 169,758 & 13,342 & 14,835 & $\mathrm{~N} / \mathrm{A}$ & $\mathrm{N} / \mathrm{A}$ \\
\hline & Agriculture & 6,710 & 6,920 & 8,104 & 660 & 744 & $\mathrm{~N} / \mathrm{A}$ & $\mathrm{N} / \mathrm{A}$ \\
\hline & Industry & 38,593 & 40,923 & 44,614 & 4,325 & 5,002 & N/A & N/A \\
\hline & - $\quad$ Mining and quarrying & 1,442 & 1,124 & N/A & N/A & N/A & $\mathrm{N} / \mathrm{A}$ & $\mathrm{N} / \mathrm{A}$ \\
\hline & $\begin{array}{l}\text { - Electricity, Gas and } \\
\text { HAC }\end{array}$ & 4,461 & 4,110 & $\mathrm{~N} / \mathrm{A}$ & $\mathrm{N} / \mathrm{A}$ & N/A & N/A & N/A \\
\hline & Construction & 9,416 & 10,299 & 10,454 & 638 & 690 & N/A & $\mathrm{N} / \mathrm{A}$ \\
\hline & ICT & 8,098 & 8,682 & 9,751 & 602 & 687 & N/A & $\mathrm{N} / \mathrm{A}$ \\
\hline & $\begin{array}{l}\text { Professional, Scientific and } \\
\text { Technical activities; activities } \\
\text { of administrative services and } \\
\text { of support services }\end{array}$ & 7,912 & 8,253 & 13,456 & 606 & 650 & N/A & $\mathrm{N} / \mathrm{A}$ \\
\hline
\end{tabular}

In Jiu Valley micro-region, the mining settlements in Petroşani basin (Petroşani, Lupeni, Petrila, Uricani, Aninoasa) first was developed as coal extraction centers and subsequently received the status of a city. According to R. Săgeată [4] in Urban Geography, as natural resources are exhausted or diminished, cities are either devolved or pass through reconversion - functional change. Closure of the exploitation has resulted in unemployment, and local communities are looking for new development alternatives such as the exploitation of the tourist heritage, recreative, sporting, environmental or industrial. Currently, major employers in the micro-region are active in the industry (mining, electricity and heat, textile and car spare parts manufacturing, water-sewage infrastructure), education and health.

According to Jiu Valley Sustainable Urban Mobility Plan (SUMP) [5], in terms of road network, the Jiu Valley micro-region has a high degree of connectivity, being connected to the Trans-European Transport Network (TEN-T Comprehensive). At the same time, within the General Transport Master Plan of Romania, the Trans-Regio Country of Hateg route is foreseen on the TEN-T network sectors in the area: Filiasi - Tg. Jiu - Petrosani - Hateg Deva - A1 (highway). In Jiu Valley micro-region, the major road infrastructure is represented by national roads - DN 66 (E 79), which cross the territory of Petroşani and DN 7A, which depart from DN 66. In the south of Petroşani, DN 66A splits from DN 66. Due 
to geographic conditions, the street network, with a length of about $415 \mathrm{~km}$, of which $60 \%$ was modernized, developed in a longitudinal structure, along Jiu River and Jiu West. Improving the quality of internal roads in the West Region and connectivity with the A1 motorway are essential to increase enterprises competitiveness. Regarding eco-friendly public transport, it should be noted that local community's concerns for the reduction of pollutant emissions are gradually yielding, Greenline project adopted by HCJ 86/2015 being promoted to be financed from ESIF (development of a public electric transport bus line to serve all settlements in Jiu Valley). Regarding the alternative modes of transport, this is a poor chapter with no deployed projects, but only planned: rehabilitation and accessibility of the pedestrian infrastructure by implementing the measures proposed in Jiu Valley SUMP, the development of both bicycle and V2G infrastructures. At the level of the railway infrastructure, the main railroad that crosses Hunedoara County is the M200, part of the TEN-T Rin - Danube (Pan - European IV) corridor connecting Curtici crossing point to Arad, Deva, Sibiu and Brasov municipalities, which is in an upgrading process as part of the project "Modernization of the Pan-European Railway corridor IV for the speed of 160 $\mathrm{km} / \mathrm{h}$ ". Sub-line 202 starts from M200 in the county's main railway junction, Simeria railway station and connects to the southern part of the county - Jiu Valley micro-region through Petroşani, Jiu and Livezeni stations. The nearest international airport is in Sibiu (neighboring Center Region), accessible in a 130-minute interval, through which the connection with destinations from Austria, Germany, Spain, Great Britain and Israel is ensured. Traian Vuia International Airport from Timisoara, 180 minutes away, provides connections to France, Germany, Belgium, Italy, Great Britain, Spain and Israel. Both Sibiu and Timisoara airports also offers domestic flights to Bucharest.

Electricity transmission networks $(400 \mathrm{kV}, 220 \mathrm{kV}$ and $110 \mathrm{kV})$ and dispatching are managed by our national TSO Transelectrica and the electricity DSO $(20 \mathrm{kV}, 6 \mathrm{kV}, 0.4 \mathrm{kV})$ is Enel Distribuție Banat, subordinated to Enel Romania. The connectivity rate to the electricity distribution network, at Hunedoara county level, is $93.8 \%$. The heat and hot water transport and distribution network is supplied by Hunedoara Energy Holding, as unique power \& heat generator and DHS operator in the area, owning 35 thermal stations (TS) out of a total of $52 \mathrm{TS}$, networks included. Other public or private DHS operators are managing the rest of $17 \mathrm{TS}$ and related networks. Several local councils took the responsibility of managing small DHS, but due to more and more people choosing the individual heating systems, the operators have to shut down their ineffective businesses (e.g. Vulcan in 2016 and probably Petroșani in 2019).

The natural gas distribution network in Hunedoara County [6] has a length of about 845 km supplying 56 localities, of which 13 municipalities and cities, including 6 municipalities and cities in the Jiu Valley, where we have a n.g. network of about $150 \mathrm{~km}$ of $\mathrm{g}$. Considering the perspective of developing new projects aimed at diversifying the natural gas pipes routes from Caspian Sea to Central Europe, as well as exploiting new offshore n.g. resources in the Black Sea perimeters, the national n.g. transmission company Transgaz started the construction of a new natural gas corridor, included in CESEC (Central East Europe Gas Connectivity) priority list. Thus, on the territory of Romania, the National Gas Transport System will be developed on the Bulgaria-Romania-Hungary-Austria corridor the BRUA [7] project with an estimated completion date in 2022, which will cross Hunedoara and Jiu Valley.

\section{Social situation}

Romania is a country of contrasts with significant regional and interregional disparities in terms of social issues and more, at local level there are lot of data difficult to quantify and delayed statistics. Additional data along with those presented in Table 2. (population, age 
distribution and life expectancy), are emphasizing statistics related to employment and unemployment rates, poverty risk and social exclusion (Table 3.).

Table 2. Romania / West Region (RO42) / Jiu Valley micro-region - population, age distribution and life expectancy. [8]

\begin{tabular}{|c|c|c|c|c|c|c|}
\hline \multirow[t]{2}{*}{ Category } & \multirow[t]{2}{*}{ Years } & \multirow{2}{*}{$\begin{array}{l}\text { Population } \\
\text { (no.) }\end{array}$} & \multicolumn{3}{|c|}{ Age distribution (no.) } & \multirow{2}{*}{$\begin{array}{c}\text { Life } \\
\text { expectancy } \\
\text { (year) }\end{array}$} \\
\hline & & & $<15 y$ & $\begin{array}{l}15-64 y / \\
\text { Working age }\end{array}$ & $>65 y$ & \\
\hline \multirow{4}{*}{ Romania } & 2015 & $19,875,542$ & $3,086,604$ & $13,413,984$ & $3,374,954$ & 75.35 \\
\hline & 2016 & $19,760,585$ & $3,066,712$ & $13,258,418$ & $3,435,455$ & 75.56 \\
\hline & 2017 & $19,644,350$ & $3,057,024$ & $13,091,697$ & $3,495,629$ & 75.73 \\
\hline & 2018 & $19,530,631$ & $3,052,479$ & $12,927,891$ & $3,550,261$ & 76 \\
\hline \multirow{4}{*}{$\begin{array}{l}\text { West } \\
\text { Region } \\
\text { (RO42) }\end{array}$} & 2015 & $1,812,183$ & 257,097 & $1,256,305$ & 298,781 & 75.04 \\
\hline & 2016 & $1,802,212$ & 256,519 & $1,240,993$ & 304,700 & 75.28 \\
\hline & 2017 & $1,792,503$ & 256,899 & $1,225,507$ & 310,097 & 75.53 \\
\hline & 2018 & $1,784,522$ & 257,877 & $1,211,220$ & 315,425 & 76 \\
\hline \multirow{4}{*}{$\begin{array}{l}\text { Hunedoara } \\
\text { County / } \\
\text { (of which } \\
\text { Jiu Valley) }\end{array}$} & 2015 & $\begin{array}{l}403,701 / \\
141,142\end{array}$ & $\begin{array}{l}55,373 / \\
19,420\end{array}$ & $\begin{array}{l}274,132 / \\
104,722 \\
\end{array}$ & $\begin{array}{l}74,196 / \\
17,000 \\
\end{array}$ & 74.6 \\
\hline & 2016 & $\begin{array}{l}398,950 / \\
139,340\end{array}$ & $\begin{array}{l}54,751 / \\
18,708\end{array}$ & $\begin{array}{l}268,719 / \\
103,229\end{array}$ & $\begin{array}{l}75,480 / \\
17,403 \\
\end{array}$ & 74.7 \\
\hline & 2017 & $\begin{array}{l}393,154 / \\
137,744\end{array}$ & $\begin{array}{l}54,075 / \\
18,159\end{array}$ & $\begin{array}{l}262,743 / \\
101,771 \\
\end{array}$ & $\begin{array}{l}76,336 / \\
17,814 \\
\end{array}$ & 74.9 \\
\hline & 2018 & $\begin{array}{l}388,600 / \\
135,989 \\
\end{array}$ & $\begin{array}{l}53,729 / \\
17,589\end{array}$ & $\begin{array}{l}257,236 / \\
100,134\end{array}$ & $\begin{array}{l}77,635 / \\
18,266 \\
\end{array}$ & 74.9 \\
\hline
\end{tabular}

*black ink - usually resident population at January 1st; blue ink - permanent resident population on July 1

Table 3. Romania / West Region (RO42) / Hunedoara County - Labour market, poverty. [9]

\begin{tabular}{|c|c|c|c|c|c|c|c|c|c|c|c|c|}
\hline Category & \multicolumn{4}{|c|}{ Romania } & \multicolumn{3}{c|}{ West Region (RO42) } & \multicolumn{3}{c|}{ Hunedoara County } \\
\hline years & $\mathbf{2 0 1 5}$ & $\mathbf{2 0 1 6}$ & $\mathbf{2 0 1 7}$ & $\mathbf{2 0 1 8}$ & $\mathbf{2 0 1 5}$ & $\mathbf{2 0 1 6}$ & $\mathbf{2 0 1 7}$ & $\mathbf{2 0 1 8}$ & $\mathbf{2 0 1 5}$ & $\mathbf{2 0 1 6}$ & $\mathbf{2 0 1 7}$ & $\mathbf{2 0 1 8}$ \\
\hline Employment rate (\%) & 66.00 & 66.30 & 68.80 & 69.90 & N/A & N/A & N/A & N/A & N/A & N/A & N/A & N/A \\
\hline Registered unemployed (th. inh.) & 436,2 & 418.2 & 351.1 & 288.9 & 25.6 & 22.1 & 18.6 & 15.0 & 11.34 & 10.78 & 7.89 & 5.83 \\
\hline Unemployment rate (\%) & 4,9 & 4.8 & 4.0 & 4.0 & 2.40 & 3.0 & 2.20 & 1.70 & 6.6 & 6.0 & 4.5 & 3.3 \\
\hline Labour transitions by pay level (\%) & 6.9 & 8.3 & 7.4 & 9.3 & N/A & N/A & N/A & N/A & N/A & N/A & N/A & N/A \\
\hline $\begin{array}{c}\text { People at risk of poverty or social } \\
\text { exclusion by NUTS regions (\%) }\end{array}$ & 37.4 & 38.8 & 35.7 & 32.5 & 32.0 & 40.7 & 32.5 & 22.1 & N/A & N/A & N/A & N/A \\
\hline $\begin{array}{c}\text { In-work at-risk-of-poverty rate by } \\
\text { months worked - EU-SILC survey } \\
\text { (\%) }\end{array}$ & 32.8 & 37.6 & 51.2 & 41.7 & N/A & N/A & N/A & N/A & N/A & N/A & N/A & N/A \\
\hline
\end{tabular}

According to the Labour Inspection Activity Reports (Law no. 544 of 2001) the number of individual active labour contracts and the number of active employees had an upward trend at national level over the period 2015-2018. Table 4. shows contracts by type and number of active employees.

Regarding Jiu Valley micro-region the number of active employees in 2015 is presented by three categories of activity sectors: primary, secondary and tertiary. 
Table 4. Romania - Employment contracts and employees. [10]

\begin{tabular}{|c|c|c|c|c|c|c|c|c|c|c|}
\hline \multirow{3}{*}{ Year } & \multirow{3}{*}{$\begin{array}{c}\text { Number } \\
\text { of } \\
\text { active } \\
\text { employees }\end{array}$} & \multicolumn{9}{|c|}{ Number of individual active labour contracts } \\
\hline & & \multicolumn{4}{|c|}{ Unlimited duration } & \multicolumn{4}{|c|}{ Limited duration } & \multirow[b]{2}{*}{ TOTAL } \\
\hline & & Full time & $\begin{array}{l}\text { Part } \\
\text { time }\end{array}$ & Total & $\%$ & $\begin{array}{l}\text { Full } \\
\text { time }\end{array}$ & $\begin{array}{l}\text { Part } \\
\text { time }\end{array}$ & Total & $\%$ & \\
\hline 2018 & $5,533,937$ & $5,151,844$ & 691,358 & $5,843,202$ & 91.61 & 308,251 & 226,511 & 534,762 & 8.39 & $6,377,964$ \\
\hline 2017 & $5,528,199$ & $5,001,008$ & 807,758 & $5,808,766$ & 92.51 & 331,756 & 138,381 & 470,137 & 7.49 & $6,278,903$ \\
\hline 2016 & $5,478,666$ & $4,763,323$ & 997,865 & $5,761,188$ & 92.34 & 346,181 & 131,798 & 477,979 & 7.66 & $6,239,167$ \\
\hline 2015 & $5,378,487$ & $4,641,738$ & 950,126 & $5,591,864$ & 91.76 & 362,156 & 139,626 & 501,782 & 8.24 & $6,093,646$ \\
\hline
\end{tabular}

Table 5. Jiu Valley - Occupied population by categories of activity sectors, 2015. [11]

\begin{tabular}{|c|c|c|c|c|c|c|c|}
\hline \multirow{2}{*}{$\begin{array}{c}\text { Territorial } \\
\text { Administrative }\end{array}$} & \multirow{2}{*}{$\begin{array}{c}\text { Total } \\
\text { Units }\end{array}$} & employees & \multicolumn{6}{|c|}{ Primary } & \multicolumn{2}{|c|}{ Secondary } & \multicolumn{2}{|c|}{ Tertiary } \\
\cline { 3 - 8 } & & Number & $\mathbf{\%}$ & Number & \% & Number & \% \\
\hline Petroşani & 14,085 & 20 & 0.14 & 6,487 & 46.05 & 7,578 & 53.8 \\
\hline Aninoasa & 1,737 & 3 & 0.17 & 1,376 & 79.21 & 358 & 20.61 \\
\hline Vulcan & 7,362 & 1 & 0.01 & 5,691 & 77.3 & 167 & 22.68 \\
\hline Uricani & 2,746 & - & - & 2,134 & 77.71 & 612 & 22.28 \\
\hline Petrila & 5,802 & 2 & 0.03 & 4,796 & 82.66 & 1,004 & 17.3 \\
\hline Lupeni & 6,077 & 4 & 0.06 & 4,196 & 69.04 & 1,877 & 30.88 \\
\hline Băniţa & 75 & 1 & 1.33 & 8 & 10.66 & 66 & 88 \\
\hline Total & 37,884 & 31 & 0.08 & 24,688 & 65.17 & 13,165 & 34.75 \\
\hline
\end{tabular}

The unemployment rate in Jiu Valley had the highest share per country (25-30\%). There are people who cannot find a job, but who represent a large potential of labour force, including staff both unqualified and qualified.

Further, in order to understand the complex and problematic social state of play in Jiu Valley micro-region, main indicators are presented for characterizing the hard coal mining sector during two crossroad years: 1990 and 2018. (Table 6.).

Table 6. Jiu Valley micro-region -Hard coal mining sector.

\begin{tabular}{|l|c|c|c|}
\hline \multirow{2}{*}{\multicolumn{1}{|c|}{ Category }} & \multirow{2}{*}{ M.U } & \multicolumn{2}{c|}{ Year } \\
\cline { 3 - 4 } & & $\mathbf{1 9 9 0}$ & $\mathbf{2 0 1 8}$ \\
\hline Jiu Valley population & inh. & 167,456 & 120,734 \\
\hline Employees in the mining sector & no. & 55,000 & 4,797 \\
\hline Mining perimeters in operation & pcs. & 17 & 4 \\
\hline Active preparation plants & pcs. & 5 & 1 \\
\hline Exploited layers & pcs. & 12 & 3 \\
\hline Gross hard coal mines production & mil.tons & 10.5 & 0.8 \\
\hline Investments in the mining sector & mil.lei & 128.59 & 0 \\
\hline Population below the poverty limit & $\%$ & - & 10.25 \\
\hline Unemployment & $\%$ & - & 1.26 \\
\hline Contribution to the local budget & $\%$ & 76 & 1.71 \\
\hline
\end{tabular}




\section{Conclusions}

The socio-economic aspects are, therefore, important and must be considered in the analyzes underlying the elaboration of policies, strategies and action plans that will generate the initiation of financial mechanisms / instruments dedicated to these areas in order to support this structural transformation / change. Based on such analyzes energy strategies, sustainable regional economic development can be developed, [12]. These roadmaps can open up new economic potentials by enhancing and fostering synergies between different local resources.

Recently (1-16 July 2019) a MoU was established and signed, called "Jiu Valley Partnership for a Right and Fair Transition", including commitment and pro-active involvement of all 6 local councils in Jiu Valley, aiming to support:

- governance development

- transition process planning and implementation

- projects identification and adequate financial mechanism and funds for deployment

- co-creation of a roadmap to pave the way to a sustainable energy transition and socio-economic development in the benefit of their citizens.

This paper opens future studies on the impact of economic decisions on local social aspects, the possibility to develop formal models that combine territorial specific features, models with territorial dimension capable of offering - through synergy, cooperation, networking and active-collective learning -growth and development opportunities.

\section{References}

1. Ministry of Energy, Strategia Energetica a Romaniei 2019-2030, cu perspectiva 2050 (Bucharest, 2018). Available on energie.gov.ro/.../Strategia Energetica FINAL 02 nov 2018.doc

2. I.V. Vlad, Strategia de dezvoltare a României în următorii 20 de ani (Academiei Romane, Bucharest, 2016)

3. National Commission for Strategy and Prognosis, Projection of the main economic and social indicators until 2021 (Bucharest, 2018). Available on http://www.cnp.ro/user/repository/prognoze/prognoza_2018_2021_varianta_de_primavara_2018. pdf

4. R. Săgeată, Geografia urbană. (Universităţii „Lucian Blaga” Sibiu, 2010)

5. Sigma Mobility Engineering SRL, Plan de Mobilitate Urbana Durabila - Green Line Valea Jiului, Consiliul Judetean Hunedoara (2018)

6. GEA Strategy \& Consulting SA, Planul de Dezvoltare Regională al Judeţului Hunedoara 2014 2020 (Deva, 2015)

7. SN Transgaz SA, Planul de dezvoltare a sistemului national de transport gaze naturale 2018 -2027 (Medias, 2017)

8. The National Institute of Statistics, INS - serii de date. Avalable on http://statistici.insse.ro:8077/tempo-online/\#/pages/tables/insse-table

9. Eurostat. Available on https://ec.europa.eu/eurostat/statisticsexplained/index.php?title=Income poverty statistics/ro

10. Labor Inspection, Activity Report for the years 2018/2017/2016/2015. Available on https://www.inspectiamuncii.ro/

11. National Agency for Employment. Available on https://www.anofm.ro/

12. S.I. Irimie, M.I. Danciu, S. Irimie, M. Mihai, Strategic Aspects in Sustainable Development of Jiu Valley, Romania, Scientific Reports on Resource Issues BHT 2016 1, 229-237 (TU Bergakademie Freiberg, Germany, 2017). 